27. Kantarjian HM, Shah NP, Cortes JE et al (2011) Dasatinib or imatinib in newly diagnosed chronic phase chronic myeloid leukemia: 2-year follow-up from a randomized phase 3 trial (DASISION). Blood 119(5):1123-1129

28. Larson RA, Hochhaus A, Hughes TP et al (2012) Nilotinib vs imatinib in patients with newly diagnosed Philadelphia chromosome-positive chronic myeloid leukemia in chronic phase: ENESTnd 3-year follow-up. Leukemia 26:2197-2203

29. le Coutre PD, Giles FJ, Hochhaus A et al (2012) Nilotinib in patients with $\mathrm{Ph}+$ chronic myeloid leukemia in accelerated phase following imatinib resistance or intolerance: 24-month follow-up results. Leukemia 26:1189-1194

30. Mahon FX, Rea D, Guilhot J et al (2010) Discontinuation of imatinib in patients with chronic myeloid leukaemia who have maintained complete molecular remission for at least 2 years: the prospective, multicentre Stop Imatinib (STIM) trial. Lancet Oncol 11:1029-1035

31. Milojkovic D, Nicholson E, Apperley JF et al (2010) Early prediction of success or failure of treatment with second-generation tyrosine kinase inhibitors in patients with chronic myeloid leukemia. Haematologica 95:224-231

32. Müller MC, Cortes JE, Kim DW et al (2009) Dasatinib treatment of chronic-phase chronic myeloid leukemia: analysis of responses according to preexisting BCR-ABL mutations. Blood 114:49444953

33. Müller MC, Cross NC, Erben P et al (2009) Harmonization of molecular monitoring of CML therapy in Europe. Leukemia 23:1957-1963

34. Nicolini FE, Basak GW, Soverini S et al (2011) Allogeneic stem cell transplantation for patients harboring T315I BCR-ABL mutated leukemias. Blood 118:5697-5700

35. O'Brien SG, Guilhot F, Larson RA et al (2003) Imatinib compared with interferon and low-dose cytarabine for newly diagnosed chronic-phase chronic myeloid leukemia. N Engl J Med 348:994-1004

36. Preudhomme C, Guilhot J, Nicolini FE et al (2010) Imatinib plus peginterferon alfa-2a in chronic myeloid leukemia. N Engl J Med 363:2511-2521

37. Rohrbacher M, Hasford J (2009) Epidemiology of chronic myeloid leukaemia (CML). Best Pract Res Clin Haematol 22:295-302

38. Saglio G, Kim DW, Issaragrisil S et al (2010) Nilotinib versus imatinib for newly diagnosed chronic myeloid leukemia. N Engl J Med 362:2251-2259

39. Saussele S, Lauseker M, Gratwohl A et al (2010) Allogeneic hematopoietic stem cell transplantation (allo SCT) for chronic myeloid leukemia in the imatinib era: evaluation of its impact within a subgroup of the randomized German CML Study IV. Blood 115:1880-1885

40. Simonsson B, Gedde-Dahl T, Markevarn B et al (2011) Combination of pegylated IFN-alpha2b with imatinib increases molecular response rates in patients with low- or intermediate-risk chronic myeloid leukemia. Blood 118:3228-3235

41. Soverini S, Hochhaus A, Nicolini FE et al (2011) BCR-ABL kinase domain mutation analysis in chronic myeloid leukemia patients treated with tyrosine kinase inhibitors: recommendations from an expert panel on behalf of European LeukemiaNet. Blood 118:1208-1215

42. Weisberg E, Manley PW, Cowan-Jacob SW et al (2007) Second generation inhibitors of BCR-ABL for the treatment of imatinib-resistant chronic myeloid leukaemia. Nat Rev Cancer 7:345-356
Onkologe 2012 · 18:1114

DOI 10.1007/s00761-012-2376-x

Online publiziert: 1. Dezember 2012

c) Springer-Verlag Berlin Heidelberg 2012

R. Knüchel-Clarke' · A. Hartmann ${ }^{2}$

${ }^{1}$ Institut für Pathologie, Universitätsklinikum Aachen

2 Universitätsklinikum Erlangen

\section{Erratum zu: Pathogenese und Tumorklassifikation des Harnblasenkarzinoms}

\author{
Onkologe 18:961-970 \\ http://dx.doi.org/10.1007/s00761-012-2334-7
}

In dem Beitrag wurde Abbildung 2 mit Abbildung 3 vertauscht. Wir bitten, den Fehler zu entschuldigen.

\section{Korrespondenzadresse}

Prof. Dr. R. Knüchel-Clarke

Institut für Pathologie,

Universitätsklinikum Aachen

Pauwelsstraße 30, 52074 Aachen

rknuechel-clarke@ukaachen.de 